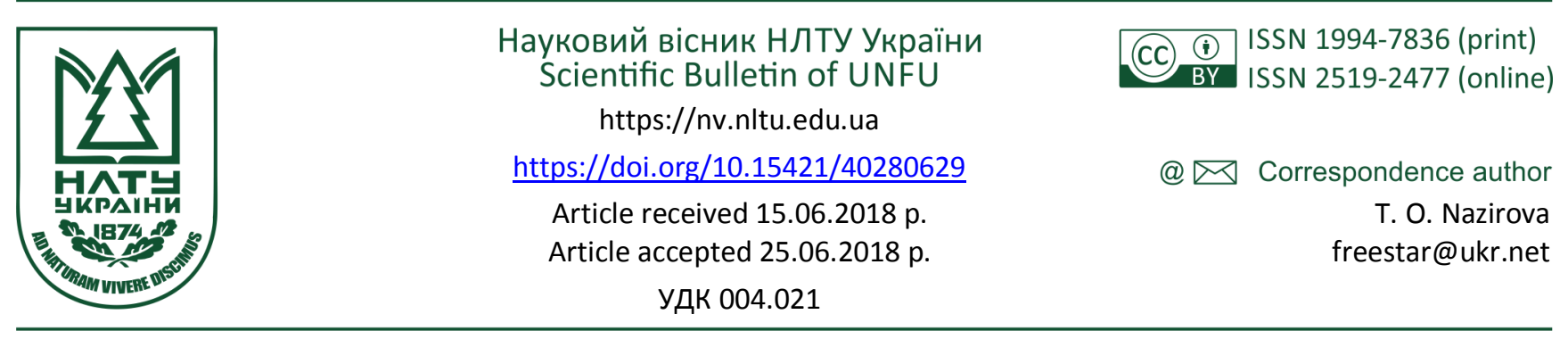

Е. К. Назіров 1 , Т. О. Назірова 1 , В. М. Лучкін ${ }^{2}$

${ }^{1}$ Харківський національний університет міського господарства ім. О. М. Бекетова, м. Харків, Украӥна ${ }^{2}$ Національний технічний університет Украӥни "Київський політехнічний інститут ім. Ігоря Сікорського", м. Київ, Украйна

\title{
АНАЛІЗ МЕТОДІВ ВИЗНАЧЕННЯ МІСЦЯ РОЗТАШУВАННЯ НАДЗВИЧАЙНОЇ СИТУАЦІЇ НА ПІДСТАВІ АКУСТИЧНИХ СИГНАЛІВ
}

Досліджено сутність та доцільність застосування систем раннього попередження надзвичайних ситуацій, на основі аналізу отриманих акустичних сигналів. Ефективне управління надзвичайними ситуаціями сприяє стабільному розвитку загальної безпеки держави і сталому розвитку економіки країни. Дії або бездіяльність у цій сфері безпосередньо впливають на здоров'я населення України та є одним з пріоритетних питань національної безпеки. Важливою проблемою в управлінні надзвичайними ситуаціями $є$ відсутність у режимі реального часу узгоджених можливостей реагування, керованих інтегрованими засобами прийняття рішень на основі інформації, отриманої від перших сигналів реакції на докризовий стан. Представлена робота спрямована на підтримку узгодженого управління надзвичайними ситуаціями в разі виникнення та розвитку надзвичайної ситуації, небезпеки великих аварій і незапланованих заходів, включаючи серію необхідних заходів для захисту суспільного життя і безпеки власності. Наведено методику виявлення звуків небезпеки в умовах міського шуму. Різноманітність звуків життєдіяльності населення величезна й охоплює звуки, створювані в приміщенні і на відкритому повітpi, так і в навколишніх будинках і спорудах. Ці звуки передають інформацію про людську і соціальну діяльність, або про загрозу виникнення надзвичайної ситуації. Сучасні методології розроблення програмного забезпечення зменшують ризик розвитку надзвичайних ситуацій, шляхом визначення та раннього виявлення епіцентру місця розташування надзвичайної ситуації. В огляді проаналізовано методи управління інформаційними ресурсами і ресурсами зберігання інформації, які потрібні для управління діяльністю в аварійних сценаріях, доповнені службою локалізації НС, яка спирається на визначення місця розташування. Методи поєднують у собі рівень сили сигналів, отриманих від орієнтирів, розташованих респондентами в докризовій системі, на основі інформації отриманих акустичних сигналів. Аудіо тріангуляція вказує на розташування небезпечної зони й алгоритми машинного навчання аналізують отримані аудіо-сигнали. Для людей і суспільства загалом потенційні надзвичайні ситуації та катастрофи накладають важкі психологічні та економічні наслідки. Потреба подальших розробок превентивних заходів профілактики й ефективного реагування мають актуальне значення в заходах щодо запобігання надзвичайним ситуаціям, ліквідації, зменшення можливих втрат і збитків, які охоплюють всі вікові групи населення. Сприяють ефективному і комплексному використанню наявних сил і методів, які призначені для запобігання НС та позитивно впливають на попередження кризи на ранніх стадіях його розвитку.

Ключові слова: надзвичайна ситуація; цивільний захист; системи сповіщення; цивільний захист населення; інформаційна система цивільного захисту.

Вступ. Існування будь-якої суверенної держави неможливе без захисту їі національних інтересів, що $\epsilon$ основною, фундаментальною умовою гарантування самозбереження й прогресивного саморозвитку суспільства. За таких причин національна безпека суспільств основне завдання будь-якого уряду, та полягає у зниженні ризику виникнення надзвичайних ситуацій техногенного, природного та соціального характеру, підвищення рівня безпеки населення і захищеності територій від наслідків аварійних ситуацій. Правові засади національної безпеки України визначено Конституцією України, Законом України "Про основи національної безпеки України" та іншими законодавчими актами.
Аналіз динаміки надзвичайних ситуацій показує, що загалом кількість надзвичайних ситуацій має тенденцію до зниження, зокрема у 2017 р. зареєстровано найменшу кількість загиблих у НС та найменшу кількість НС техногенного характеру за період спостережень 19972017 рр. Але загалом кількість надзвичайних ситуацій та їх економічні наслідки, порівняно з подібними часовими періодами європейських держав, показують, що Україна має низькі показники безпеки (DSNS, 2018). Також соціологічні опитування свідчать, що рівень ставлення громадян до органів системи внутрішніх справ, порівняно з іншими сталішими державами, низький: Державна служба з надзвичайних ситуацій має до-

Інформація про авторів:

Назіров Ельдар Кямалович, здобувач, менеджер інформаційних технологій ООО Метінвест Бізнес Сервіс Україна, м. Кривий Ріг. Email: freestar@ukr.net

Назірова Тетяна Олександрівна, здобувач, старший інженер комп'ютерних систем ООО Метінвест Бізнес Сервіс Україна, м. Кривий Ріг. Email: freestar@ukr.net

Лучкін Володимир Миколайович, асистент, кафедра ACOІУ. Email: wladimir.luchkin@gmail.com

Цитування за ДСту: Назіров Е. К., Назірова Т. О., Лучкін В. М. Аналіз методів визначення місця розташування надзвичайної ситуації на підставі акустичних сигналів. Науковий вісник НлтУ України. 2018, т. 28, № 6. С. 147-151.

Citation APA: Nazirov, E. K., Nazirova, T. A., \& Luchkin, V. M. (2018). Analysis methods position determination of emergency on the basis of acoustic signals. Scientific Bulletin of UNFU, 28(6), 147-151. https://doi.org/10.15421/40280629 
віру громадян - 50,5 \%, Національна поліція - 39,3 \%, Департамент патрульної поліції - 40,9%. На відміну від показників довіри службам реагування в надзвичайних ситуаціях європейських держав, наприклад: Фінляндія - 91 \%, Великобританія - 89 \%, Данія - 86,6 \%, Нiдерланди - 79 \%, Швейцарія - 78,3 \%, Германія - 74 \% (HFA-DB, 2018).

Аналіз останніх досліджень та публікачій показав, що антикризове врядування є предметом наукового інтересу багатьох сучасних науковців як в Україні, так i поза іï межами. Теоретичні, методологічні засади та практичний інструментарій менеджменту надзвичайних ситуацій досліджували такі науковці, як: І. А. Чуб (2014), М.В.Новожилова (2014), О.В.Львов (2010), В. М. Попов та ін. Зі зарубіжних науковців варто виокремити праці: John J. Fay (2018), Michael Khalemsky (2017), A. Malizia (2010), Sue lynn Choy (2016), Shuo Wan (2017) та ін..

Однак, треба зазначити, що більшість досліджень стосувалися техногенних надзвичайних ситуацій, але на сьогодні вирішення проблем громадської безпеки за нестабільних умов політичного стану в країні залишається вкрай актуальною і потребує грунтовнішого дослідження з погляду запобігання та подолання кризових явищ. Отже, актуальність означеної проблематики та перспективи іiі вирішення визначили пріоритетність напряму дослідження та окреслили мету.

Означена мета може бути реалізована шляхом виконання таких завдань (Nazirov \& Nazirova, 2018):

- визначити наявні методи детермінації місця розташування НС на основі отриманих аудіо-сигналів;

- дослідити та систематизувати ключові характеристики звукометричної персональної системи оповіщення про настання надзвичайної ситуації АcЕН;

- довести об'єктивну потреба запровадження та використання інформаційних систем раннього виявлення НС, для подолання кризових явищ та недопущення розвитку загрозливого становища подій.

Матеріал та методи дослідження. Системи раннього виявлення надзвичайних ситуацій набули поширення в усьому світі, оскільки можуть сприяти попередженню загроз життю громадян від злочинної діяльності та мінімізувати втрати від наслідків аварійного стану. Також для сил правопорядку системи виконують функції пошуку злочинців, виявлення протиправних дій, ефективного розподілення наявних людських та матеріальних ресурсів. На сьогодні широкого застосування набули камери спостереження, які встановили в багатьох публічних місцях, таких як банки, супермаркети, залізничні станції, а також інші місця скупчення людей, які вважають місцями злочинності з високою вірогідністю. Дані з цих камер записуються або відображаються на обладнанні служб охорони громадського порядку, які постійно зайняті моніторингом безпеки та стежать за підозрілою діяльністю.

Викладення основного матеріалу дослідження. У звітах служб України з надзвичайних ситуацій та Міністерства внутрішніх справ наголошено, що системи відеоспостереження виявляють лише факт проникнення на територію, але не надають потрібної інформації для розкриття злочинів (місце розташування злочину, кількість осіб та масштаби лиха) та обмежені у генеруванні сигналів тривоги. Це пов'язано з використанням недосконалих методів розпізнавання, застарілим обладнан- ням та відсутністю інтелектуальних складників означених систем. Немає також централізованого підходу, або стандартів, до створення подібних інформаційно-аналітичних систем у державі (DSNS, 2018).

Ефективне нагромадження, аналіз та застосування даних, їх інтелектуальне використання стають дедалі важливішими у цій галузі. Отже, розвиток розробок інформаційних систем раннього виявлення надзвичайних ситуацій $є$ пріоритетним завданням у галузі безпеки.

Розглянемо метод визначення місця розташування джерела звуку підсистемою ідентифікації звуку звукометричної персональної системи оповіщення про настання надзвичайної ситуації Асен (Nazirov, 2015). Система призначена для реєстрації сигналів про потенційну загрозу, їх подальше оброблення, включаючи ідентифікацію характеру загрози, динаміку і напрямок іiі поширення, сповіщення користувача системи з наданням рекомендацій і правил поведінки в разі настання конкретної надзвичайної ситуації.

Для розпізнавання інтенсивного короткочасного звуку використовуємо метод фільтрації рівнів гучності звуку. Цей метод характеризується високою швидкодією і невисокими затратами на апаратну реалізацію. 3 його недоліків варто зазначити середню ефективність. Паралельно до запису відбувається відстеження поточного рівня сигналу, що надходить на мікрофон, і його порівняння в режимі реального часу зі середнім рівнем сигналу (рівень фонового шуму), отриманим 3 попереднього файлу. Якщо поточний рівень сигналу перевищує середній в $\mathrm{N}$ і більше разів, то система формує сигнал ідентифікації події на підсистему аналізу і прийняття рішень (Malizia et al., 2010).

Підсистема аналізу і прийняття рішення:

- отримавши в заданому інтервалі часу сигнали від великої кількості (десятки пристроїв) клієнтських підсистем, що розташовані у відносній близькості один від одного, приймає рішення про настання події, а саме розпізнаванні інтенсивного короткочасного звуку, і починає процедури визначення передбачуваного місцезнаходження та ідентифікації джерела інтенсивного короткочасного звуку;

- отримавши в заданому інтервалі часу сигнали від деякої кількості (одиниці пристроїв) клієнтських підсистем, що знаходяться у відносній близькості один від одного, приймає рішення про потреба підтвердження настання подіï, i починає процедуру пошуку передбачуваної події на клієнтських підсистемах, розташованих у відносній близькості від систем, ідентифікуючи події. Пошук проводиться шляхом відправлення запитів на повторний аналіз збережених файлів, і пошук у них рівнів потужності звуку, відмінних від фонового, але через недостатню потужність, що не призвели раніше до відправки сигналу ідентифікації події на підсистему аналізу і прийняття рішень. У разі підтвердження знаходження перевищення рівнів потужності над фоновим в заданий інтервал часу на великій (десятки пристроїв) кількості клієнтських підсистем, які після повторного аналізу відправили сигнали ідентифікації події на підсистему аналізу і прийняття рішення, остання починає процедури визначення передбачуваного місцезнаходження та ідентифікації джерела інтенсивного короткочасного звуку;

- отримавши в заданому інтервалі часу сигнали від однієї або пари клієнтських підсистем, що розташовані у відносній близькості один від одного, приймає рішення про помилкове спрацьовування і не приймає рішення про реєстрацію інтенсивного короткочасного звуку.

У перших двох випадках підсистема аналізу i прийняття рішення запускає процедури: 
- процедура визначення передбачуваного місцезнаходження джерела інтенсивного короткочасного звуку виконується шляхом відправлення запитів про поточне місцезнаходження клієнтських підсистем, що зареєстрували настання події;

- отримані дані про місцезнаходження клієнтських підсистем і часу зареєстрованої події обробляються за допомогою триангуляційних методів визначення координат джерела звуку.

Точна локалізація місць генерації і випромінювання акустичних хвиль, будучи актуальною технічною проблемою, виникає в разі виявлення місць технологічних вибухів, пусків ракет, ударів блискавок, джерел небезпечних інфразвуків тощо (Choy et al., 2016). Ці та інші подібні завдання досі в основному вирішувалися триангуляційним акустичним методом, основні недоліки якого такі:

1. Істотними операціями є визначення швидкості звуку $\mathrm{i}$ точна реєстрація часу надходження акустичних хвиль. Однак, як відомо, температура і вологість значно впливає як на швидкість звуку, так і на затухання акустичних хвиль, що в кінцевому підсумку, призводить до похибки обчислення.

2. Точність оцінки потужності джерела залежить від точності триангуляційної процедури локації.

Звичайною проблемою у вимірах є шуми, перешкоди за низького рівня корисного сигналу, через це завдання визначення координат об'єкта може стати нестійким. Тому додатковою вимогою щодо розроблюваного методу визначення координат $\epsilon$ можливість використання в розрахунках достатньої кількості клієнтських систем, які приймають помітний сигнал, для підвищення точності визначення координат.

Для усунення зазначених недоліків пропонуємо принципово новий підхід до вирішення задачі локації, що полягає у використанні результатів вимірювання ступеня ослаблення акустичних хвиль. При цьому замість триангуляційних обчислень і відповідних геометричних побудов використовують ітераційну процедуру побудови кіл, центри яких збігаються з точками розташування приймальних мікрофонів смартфонів користувачів системи, а радіуси цих кіл пропорційні до ступеня ослаблення прийнятої акустичної хвилі. Показано, що запропонований метод також дає змогу визначити потужність випромінюваної акустичної хвилі у джерела.

Усі зазначені вище недоліки триангуляційного методу можуть бути усунені, якщо відмовитися від тригонометричного способу обчислень і використовувати фізичні та геометричні основи процесу поширення акустичної хвилі для вирішення даного завдання, що зроблено в пропонованому методі кіл. Насамперед розглянемо фізичні основи пропонованого методу. Як відомо, наприклад, для плоскої акустичної хвилі амплітуду звукового тиску Р на відстані х можна розрахувати за такою формулою:

$$
P=P_{0} e^{-\frac{m x}{2}},
$$

де: $P_{0}$ - амплітуда тиску звукових хвиль у точці $x=0$; $m$ - загальний коефіцієнт ослаблення. Вплив навколишнього середовища на швидкість звуку проілюстровано графіками залежності від відносної вологості за температури $20^{\circ} \mathrm{C}$ для різних частот (рис. 1).

Зазначимо, що загальний коефіцієнт ослаблення залежить як від відносної вологості, так і від температури. При цьому треба врахувати, що такі параметри як температура i відносна вологість $є$ термодинамічно пов'язаними параметрами і не можуть бути розглянуті в ролі лінійно незалежних параметрів. 3 цієї причини метод локації джерел звукових хвиль передбачає наявність відомостей про значення температури за фіксованих величин відносної вологості. На рис. 2 представлено графіки для формули (2) при $R H=50 \%$.

$$
m=f\left(F, t^{0}\right) \text {. }
$$

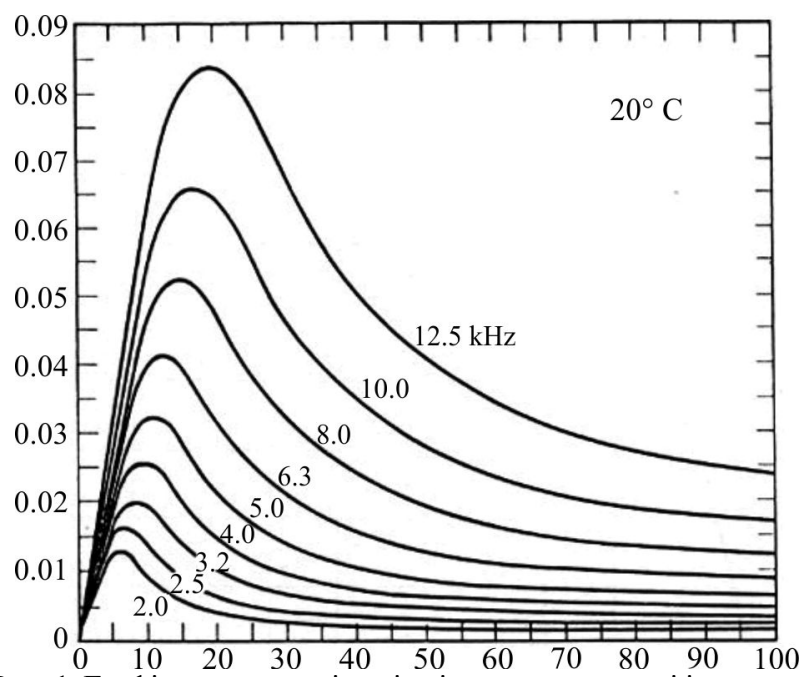

Рис. 1. Графіки залежності m від відносної вологості і частоти

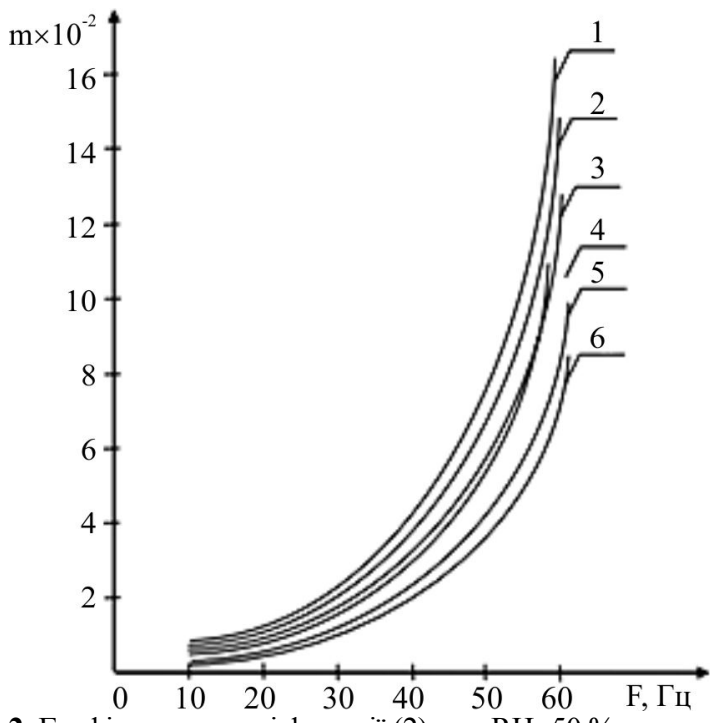

Рис. 2. Графік залежності функції (2) при $\mathrm{RH}=50$ \%

Цифрами позначено $1-t^{0}=5^{0}, 2-t^{0}=10^{0}, 3-t^{0}=$ $15^{0}, 4-t^{0}=20^{0}, 5-t^{0}=25^{0}, 6-t^{0}=30^{0}$.

Відомо, що у сферичної хвилі, внаслідок розширення фронту, амплітуда тиску обернено пропорційна до відстані від джерела $x$. Тому отримаємо:

$$
P(x)=\frac{P_{0}}{x} * e^{\frac{-m x}{2}} .
$$

Пропонований метод локації на основі побудови кіл приведемо до такого вигляду:

$$
x-\frac{2}{m} \ln \frac{1}{x}=a-\frac{2}{m} \ln P(x),
$$

де $a=\frac{2}{m} \operatorname{In} P_{0}$.

Очевидно, що за фіксованих величин температури i вологості, 3 використанням трьох мікрофонів, отримуємо таку систему трансцендентних рівнянь:

$$
x_{1}-\frac{2}{m} \operatorname{In} \frac{1}{x}=a-\frac{2}{m} \operatorname{In} P\left(x_{1}\right),
$$




$$
\begin{aligned}
& x_{2}-\frac{2}{m} \operatorname{In} \frac{1}{x}=a-\frac{2}{m} \operatorname{In} P\left(x_{2}\right), \\
& x_{3}-\frac{2}{m} \operatorname{In} \frac{1}{x}=a-\frac{2}{m} \operatorname{In} P\left(x_{3}\right) .
\end{aligned}
$$
тимо, що параметр т відомий, $a$ - невідомий. В цьому випадку процедура локації складається з таких кроків:

1. Встановлюються мікрофони $M_{1}, M_{2}, M_{3}$.

2. Здійснюється вимірювання $P\left(x_{1}\right), P\left(x_{2}\right), P\left(x_{3}\right)$.

3. Оскільки а невідомий, задаються приблизною величиною а.

4. Вирішується система трансцендентних рівнянь (4) щодо $x_{1}, x_{2}, x_{3}$, внаслідок чого отримуємо відповідні розрахункові значення $x_{1 p}, x_{2 p}, x_{3 p}$.

Здійснюють геометричні побудови в такому порядку. Місце знаходження мікрофона вибирається в ролі центру $s$-ї окружності, радіус якої дорівнює $x_{i p}$. Припустимо, що під час первинної побудови кіл отримаємо трикутну форму $S_{1}, S_{2}, S_{3}$. Далі, щоб звузити цю фігуру до фактично точкової ділянки, зменшуємо прийняте значення на певну величину і здійснюємо повторне обчислення величин $x_{i p}$, які на рис. 3 позначено як $x_{1 p}^{\prime}, x_{2 p}^{\prime}$, $x_{3 p}^{\prime}$. Повторна геометрична побудова дає нам дрібнішу трикутну фігуру, що містить шукане джерело акустичних хвиль.

Результати. Зазначені побудови більш дрібних трикутних форм супроводжуються зміною величини а (а отже, і $P_{0}$ ) доти поки ці форми не перетворяться в точку. Отже, запропонований метод дає змогу визначити не тільки місцезнаходження джерела акустичних сигналів, але і потужність випромінювання цього джерела, тобто розпізнати тип джерела випромінювання.

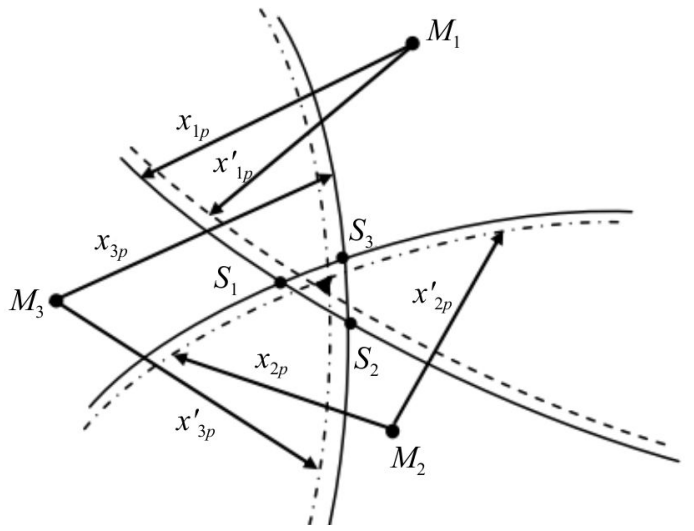

Рис. 3. Процедура локації за запропонованим методом

Точність обчислення місцезнаходження джерела звуки залежить від кількості клієнтських систем, що зареєстрували аудіо подію. Збільшення кількості смартфонів користувачів, які зареєстрували подію, істотно збільшує точність локалізації події, але і підвищує складність обчислень за запропонованим методом. У разі настання заданої величини похибки у визначенні
Варіант реалізації запропонованого методу: припус-

місця розташування об'єкта, доцільно припиняти процес обчислення для економії обчислювальних потужностей.

Висновки. Отже, проаналізовано відомі методи, підходи та технології до побудови інтелектуальних систем щодо раннього виявлення НС на основі отриманих аудіо сигналів. Запропоновано методики інтегрованої системи аналізу аудіо-сигналу та алгоритм функціонування цієї системи, яка охоплює процедуру локації за запропонованим методом небезпечних об'єктів. Запропоновано підхід до побудови сучасних інформаційних систем управління безпекою.

\section{Перелік використаної літератури}

Choy, S. L., Handmer, J., Whittaker, J., Shinohara, Y., Hatori, T., \& Kohtake, N. (2016). Application of satellite navigation system for emergency warning and alerting. Computers, Environment and $\begin{array}{lll}\text { Urban Systems, } & 58, & 12-18 .\end{array}$ https://doi.org/10.1016/j.compenvurbsys.2016.03.003

Chub, I. A., Novozhilova, M. V., \& Andronov, V. A. (2014). Matematicheskie modeli i metody proektirovaniia sistem rannego obnaruzheniia pozhara. Kharkov: NUTcZU. 148 p. [In Russian].

Dorasamy, M., Ramana, M., \& Kaliannan, M. (2017). Integrated community emergency management and awareness system: A knowledge management system for disaster support. Technological Forecasting and Social Change, 121, 139-167. https://doi.org/10.1016/j.techfore.2017.03.017

DSNS (2018). Derzhavna sluzhba Ukrainy z nadzvychainykh sytuatsii. Retrieved from: http://www.dsns.gov.ua/.

Fay, J. J., \& Patterson, D. (2018). Emergency Management (chapter 15) in Contemporary Security Management (4th ed.), (pp. 301339). https://doi.org/10.1016/B978-0-12-809278-1.00015-3

HFA-DB (2018). European health for all database. Retrieved from: http://data.euro.who.int/hfadb/

Khalemsky, M., \& Schwartz, D. G. (2017). Emergency Response Community Effectiveness: A simulation modeler for comparing Emergency Medical Services with smartphone-based Samaritan response. Decision Support Systems, 102, 57-68. https://doi.org/10.1016/j.dss.2017.07.003

Lvov, A. V., Agapov, M. N., \& Tishhenko, A. I. (2010). Trianguliatcionnaia sistema opredeleniia koordinat istochnika zvuka, Polzunovskii vestnik, 2, 159-162. Retrieved from: http://elib.altstu.ru/elib/books/Files/pv2010 02/pdf/158lvov.pdf

Malizia, A., Onorati, T., Diaz, P., Aedo, I., \& Astorga-Paliza, F. (2010). An ontology for emergency notification systems accessibility. Expert Systems with Applications, 37(4), 3380-3391. https://doi.org/10.1016/j.eswa.2009.10.010

Nazirov, E. K. (2015). Ispolzovanie zvukometrii v personalnoi sisteme opoveshheniia o nastuplenii chrezvychainoi situatcii. Kompiuterni tekhnologii v miskomu ta regionalnomu gospodarstvi: mater. Mizhnar. nauk.-prakt. internet-konf, (pp. 155-156). Kharkiv: KhNUMG im. O. M. Beketova. [In Russian].

Nazirov, E. K., \& Nazirova, T. A. (2018). Emergency notification system "ACEH". Scientific Bulletin of UNFU, 28(1), 140-144. https://doi.org/10.15421/40280128

Wan, Sh., Lu, J., Fan, P., Letaief, Kh. B. (2017). To Smart City: Public Safety Network Design for Emergency. IEEE Access, 6, 1451-1460. https://doi.org/10.1109/ACCESS.2017.27791373

Э. К. Назиров 1 , Т. А. Назирова ${ }^{1}$, В. М. Лучкин ${ }^{2}$

${ }^{1}$ Харьковский начиональный университет городского хозяйства им. А. Н. Бекетова, г. Харьков, Украина ${ }^{2}$ Национальный технический университет Украины "Киевский политехнический институт им. Игоря Сикорского", г. Киев, Украина

\section{АНАЛИЗ МЕТОДОВ ОПРЕДЕЛЕНИЯ МЕСТОПОЛОЖЕНИЯ ЧРЕЗВЫЧАЙНОЙ СИТУАЦИИ НА ОСНОВАНИИ АКУСТИЧЕСКИХ СИГНАЛОВ}

Исследованы сущность и целесообразность применения систем раннего предупреждения чрезвычайных ситуаций, на основе анализа полученных акустических сигналов. Эффективное управление чрезвычайными ситуациями способствует стабильному развитию общей безопасности государства и устойчивого развития экономики государства. Действия или бездей- 
ствие в этой сфере непосредственно влияют на здоровье населения Украины и являются одним из приоритетных вопросов национальной безопасности. Важной проблемой в управлении чрезвычайными ситуациями является отсутствие в режиме реального времени согласованных возможностей реагирования, управляемых интегрированными средствами принятия решений на основе информации, полученной от первых сигналов реакции на докризисное состояние. Представленная работа направлена на поддержку согласованного управления чрезвычайными ситуациями в случае возникновения и развития чрезвычайной ситуации, опасности крупных аварий и незапланированных мероприятий, включая серию необходимых мер для защиты общественной жизни и безопасности собственности. Представлена методика выявления звуков опасности в условиях городского шума. Разнообразие звуков жизнедеятельности населения огромное и включает звуки, создаваемые в помещении и на открытом воздухе, так и в окружающих зданиях и сооружениях. Эти звуки передают информацию о человеческой и социальной деятельности или об угрозе возникновения чрезвычайной ситуации. Современные методологии разработки программного обеспечения уменьшают риск развития чрезвычайных ситуаций, путем определения и раннего выявления эпицентра местоположения чрезвычайной ситуации. В обзоре представлен анализ методов управления информационными ресурсами и ресурсами хранения информации, которые необходимы для управления деятельностью в аварийных сценариях, дополненные службой локализации ЧС, которая опирается на определение местоположения. Методы сочетают в себе уровень силы сигналов, полученных от ориентиров, расположенных респондентами в докризисной системе, на основе информации полученных акустических сигналов. Аудио триангуляция указывает на расположение опасной зоны, а алгоритмы машинного обучения анализируют полученные аудио-сигналы. Для людей и общества в целом потенциальные чрезвычайные ситуации и катастрофы накладывают тяжелые психологические и экономические последствия. Необходимость дальнейших разработок превентивных мер профилактики и эффективного реагирования имеют актуальное значение в мероприятиях по предотвращению чрезвычайных ситуаций, ликвидации, уменьшения возможных потерь и убытков, охватывающие все возрастные группы населения. Способствуют эффективному и комплексному использованию имеющихся сил и методов, которые предназначены для предотвращения ЧС и положительно влияют на предупреждение кризиса на ранних стадиях его развития.

Ключевые слова: чрезвычайная ситуация; гражданская защита; системы оповещения; гражданская защита населения; информационная система защиты.

E. K. Nazirov' ${ }^{1}$ T. A. Nazirova ${ }^{1}$, V. M. Luchkin ${ }^{2}$

${ }^{1}$ O. M. Beketov National University of Urban Economy, Kharkiv, Ukraine

${ }^{2}$ National Technical University of Ukraine "Igor Sikorsky Kyiv Polytechnic Institute", Kyiv, Ukraine

\section{ANALYSIS METHODS POSITION DETERMINATION OF EMERGENCY} ON THE BASIS OF ACOUSTIC SIGNALS

The article is devoted to the investigation of the essence and expediency of the use of early warning systems for emergencies, based on the analysis of the received acoustic signals. Effective management of emergencies contributes to the stable development of the overall security of the state and the sustainable development of the state's economy. Actions or omissions in this area directly affect the health of the population of Ukraine and are one of the priority issues of national security. Many emergencies cause an immediate danger to the life of people involved. Most developed countries have a number of emergency services operating within them, whose purpose is to provide assistance in dealing with any emergency. Preventive measures are most effective when they involve participation at all levels, from the local community through the national government to the regional and international level. A critical challenge in emergency management is the lack of real-time coordinated reaction capabilities driven by integrated decision making facilities based on the information obtained by first responders acting on the crisis site. Therefore this work aims at supporting coordinated emergency management in the event of an emergency, major accident hazard, or unplanned event, including a series of necessary measures to protect public life and property safety. The article presents a technique for identifying sounds of danger in urban noise conditions. The variety of sounds of vital activity of the population is huge and includes sounds created indoors and outdoors conveying information about human and social activities or about the threat of an emergency. Modern software development methodologies reduce the risk of emergencies, by identifying and early detection of the epicentre location of an emergency. The review presents an analysis of the management methods of information resources and information storage resources that are needed to manage activities in emergency scenarios, supplemented by the emergency localization service, which relies on location determination. The methods combine the strength of signals received from landmarks located by respondents in the precrisis system, based on the information of the received acoustic signals. Audio triangulation indicates the location of the danger zone, and machine learning algorithms analyze the received audio signals. Thus, for people and society as a whole, potential emergencies and catastrophes impose severe psychological and economic consequences. The need for further development of preventive measures of prevention and effective response is of current importance in measures to prevent emergencies, eliminate, and reduce possible losses, covering all age groups of the population, and also promote the effective and integrated use of existing forces and methods that are designed to prevent emergencies and positively influence the prevention of the crisis in the early stages of its development.

Keywords: emergency response; community; simulation; emergency response information systems; emergency information system. 